\title{
Chremylus encounters Blepsidemus: The first quiproquo? (Aristophanes' Wealth 332-414)
}

\author{
Claudia N. Fernández \\ (National University of La Plata; CONICET)
}

\begin{abstract}
Blepsidemus is associated with the comic figure of the bomolochos, as he serves as a ludicrous counterpoint for Chremylus in his debate with Poverty. But the moment in which Blepsidemus demonstrates all of his potential as a dramatic character occurs during the previous scene to the agon (vv. 332-414), when he takes part in a dialogue with his friend. This was highlighted as the only example of quiproquo ("misunderstanding") in Aristophanes' plays. The aim of this paper is to explore the aesthetic efficacy of its composition and its semantic impact on the comedy.
\end{abstract}

\section{Keywords}

quiproquo; bomolochos; Blepsidemus; Aristophanes' Wealth 
In Plutus - or Wealth - the last surviving comedy by Aristophanes (388 BC), the utopian desire of the peasant Chremylus, namely, to make all honest men rich, becomes reality. ${ }^{1}$ This results in a veritable upending of the situation in Athens, in which only the wicked had wealth. ${ }^{2}$ Chremylus' great idea is inspired by Apollo, who spoke to him through the oracle and instructed him to follow the first man he met. ${ }^{3}$ This man turned out to be Plutus, the god of wealth, who had been blinded by Zeus so that he could not recognize the virtuous and lift them out of poverty. ${ }^{4}$ In order to have his eyesight restored, Plutus is taken to the temple of Asclepius: however, before this can be done, Chremylus has to confront Penia, the personification of poverty. ${ }^{5}$ The dialectical debate that ensues between the two gives rise to the formal agon of the comedy. Although Poverty's arguments are based on sound reasoning, it is clear that she is doomed to fail and to be rejected, because the negative qualities she represents have no place in the justice-oriented fiction of comedy.

1 This paper benefited from the support of the projects: "Palabras, cuerpos, objetos: soportes discursivos y materiales de las emociones en la comedia griega" (PIP CONICET 11220170100530C 2017-9) and "Pensar las emociones en la Atenas democrática: diálogo entre la comedia y la filosofía" (Programa Logos Fundación BBVA). We thank the anonymous reviewers for their careful readings of the manuscript and their insightful suggestions that helped to improve and clarify this article.

2 Unless indicated otherwise, we have followed Sommerstein's edition (2001); all of the translations are our own. Certain peculiarities - such as the reduced role of the chorus, obscenities and personal invective; the increasing role of the slave; the lack of parabasis; and the focus on the social rather than the strictly political matters - have led the play to be considered an exemplar of Middle Comedy. To a certain extent, it was received negatively by the critics, who seem to have been influenced by elements external to its artistic quality, such as the advanced age of the author or the political and economic decadence of fin de siècle Athens; more recently, however, it has been reassessed and is now justifiably viewed in a more positive light (see Olson 1990; Sfyroeras 1996; McGlew 1997; Revermann 2006). Some 20 years earlier, Aristophanes wrote another comedy of the same title. Strictly speaking it is impossible to determine the relationship between the two; with regard to this point, see MacDowell (1995: pp. 324-327); Sommerstein (2001: pp. 28-33) and MacDowell (2002), where the author admits he may have misinterpreted a scholium, but nevertheless objects to Sommerstein's proposition.

3 Chremylus asked the oracle whether - as he supposes - his son should abandon the path of decency in order to achieve a more carefree route through life (32-38). Contemporary philosophers and orators give an account of an economic and social crisis that matches the situation described in the comedy. However, by the time the play was performed the outlook had improved in comparison to previous years; see Dillon (1987); Strauss (1986); David (1984). Additionally, the ideas expressed in the comedy, such as the linking of corruption to wealth or the unfettered desire for wealth, are also expressed in the work of poets such as Theognis and Solon.

4 Plutus' blindness did not only prevent him from recognizing those who were honest, it also prevented him from creating wealth through his presence alone. In other words, it robbed him of his power.

5 Wealth and Poverty are two allegorical personifications. The case of Wealth is more complex, as it refers not only to the concept of wealth and the state of being wealthy, but also to the objects that represent wealth and to wealthy men themselves. Plutus is a pre-Olympian deity whose presence in literature can be traced back to Hesiod (Theogonia 969-974) and the Homeric Hymn to Demeter (486-489). See also Hipponax (29 D); Timocreon (5 D); for other examples, see Olson (1990: p. 226); Sfyroeras (1996: p. 234); and especially Tottaro (2016). Penia also appears as a personification in Alcaeus (frg. 364) and Herodotus (VIII.111.3), although unlike Plutus she is not a deity. Much has been written on her controversial argumentation in the agon, in which she assigns to herself the same benefits to the lives of men that Chremylus had associated with Plutus. Regarding her allegorical value, and also the agon in particular, see Newiger (1957); Gelzer (1960); Komornicka (1964). 
Like other Aristophanic heroes, Chremylus is not alone when he is debating with Penia: he is accompanied by a buffoon or fool-type figure, who disappears during the second part of the play. We are referring to Blepsidemus, the protagonist's friend, whose dramatic role was associated with the comic figure of the bomolochos, a minor character who interrupts the dialogue in order to provoke laughter. The existence of stock characters in Old Comedy has been widely debated, owing to the idiosyncratic nature of the majority of its characters, which serves to distance them from the conventions of stereotypes. However, some of them are clearly predecessors of the character types found in Middle and New Comedy - e.g. the emancipated slave, the courtesan, the flatterer, the boastful soldier, among others -, which leads us to consider the recurrence of certain components of a more or less coded nature in combination with other, more individualistic, traits. ${ }^{6}$ The bomolochos, in particular, has been shown to play a clearly defined role in Aristophanes's dramas as a humorous sidekick for the protagonist, particularly in the agon. Taking the words of the other character as their starting point, he seeks to create humour through burlesque commentaries, unexpected changes of subject, plays on words, and irrelevant or obscene anecdotes. ${ }^{7}$ They are usually ignored by the other characters and their words do not usually have a direct impact on the events of the comedy itself. ${ }^{8}$

Most of the writers who have explored the bomolochos have indicated that he is a nonfixed or movable character type, and that can be assumed by the same character throughout the whole play or only partially assumed at a particular moment within the plot. It is a role usually assigned to secondary characters, although characters such as Euripides in Acharnians and Socrates in Clouds have also been classed as bomolochoi ${ }^{9}$ Carrière (1979:

6 On this topic, see Ruffell (2014). Various authors have postulated a stereotype-based classification for Aristophanes' characters, like Thiercy (1986); McLeish (1980); Carrière (1979).

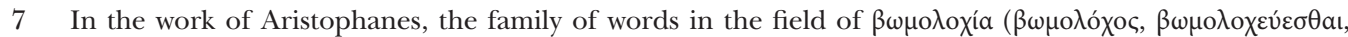
$\beta \omega \mu \mathrm{\gamma}$ ó $\varepsilon v \mu \alpha)$ is linked to buffoon-esque behaviour and to a deceptive form of discourse designed to obtain some type of advantage, without any reference or allusion to any form of comic mask. In the context of comic poetics, it represents an allusion to a type of vulgar humour, which Aristophanes assigns to his adversaries (Peace 748, Frogs 358). The proposed etymology for the word which is based on the association of the terms $\beta \omega \mu$ ó and $\lambda$ ó $о$ oৎ ("altar-ambushing"), refers to a type of beggar who hides and waits for an opportunity to make off with some of the meat from a sacrifice (see Chantraine 1999: p. 204). This has recently been questioned by Kidd (2012), who considers it an invention of the Second Sophistic, based on the testimony of Pherecrates (fr. 150KA) and Aristophanes (Knights 1194), who effectively link it to begging and theft; however, these would be nothing more than examples of false etymologies, much beloved in the realm of comic invention. In relation to bomolochia, see the aforementioned Kidd (2012); Frontisi-Ducroux (1984); Orfanos (2000); Wilkins (2000: pp. 88-90); Beta (2004: pp. 249-254); Caciagli \& Corradi \& Regali (2016).

8 In the Tractatus Coislinianus (XII), the bomolochos forms part of the triad of comic types, along with the eiron and the alazon. Since its publication in 1839, it has generated an endless amount of debate regarding its connection to the second part of Aristotle's Poetics. Those who defend the Peripatetic origins of the aforementioned Tractatus have observed that Aristotle himself linked the bomolochos to the eiron (Rh. 1419b6ff.; EN 1128a4-7; EE 1234a3-23). See also Janko (1984: pp. 42-90) with regard to this point.

9 For Süss (1908) the bomolochos is the opposite of the alazon. Neither of them is static; rather, in different comedies they are embodied in very disparate figures. Cornford (1914) takes the typology proposed by Süss and adapts it: while the alazon figures are differentiated from one another by their professions, the bomolochos has no independent existence, with the exception of subordinate figures such as slaves. 
p. 128) has denied the bomolochos the status of a dramatic role, precisely because it lacks defined psychosocial traits. As such, it is seemingly just a simple linguistic register: however, even if that should be the case, the interruptions of the bomolochos can still be considered an integral part of the action, given that in Old Comedy language determines the rhythm of the dramatic progression. ${ }^{10}$

In the case of Blepsidemus, we can observe that he effectively serves as a counterpoint for Chremylus in his debate with Penia, and more so in the proagon than in the agon proper. His cowardly behaviour - he flees at the sight of Penia (417, 438, 440, 442-444, 449-451) - and burlesque comments (he compares Penia to an Erinys, 423-424; or a tavern-keeper, 435-436), probably limited in number by his fear, correspond to his ludicrous role $(426,484,499,566,581,613-618) .{ }^{11}$ However, the moment in which Blepsidemus demonstrates all of his potential as a dramatic character does not occur during the agon; rather, it occurs during the previous scene, when he takes part in a dialogue with Chremylus just after he reaches the orchestra (332-414). ${ }^{12}$ It is this dialogue that we are concerned with herein, in order to explore the aesthetic efficacy of its composition and its semantic impact on the comedy.

Thiercy has highlighted this scene as the only example of quiproquo ("misunderstanding") in Aristophanes's plays, and therefore the first such example in Western theatre. ${ }^{13}$ This detail is of no little significance, if we consider the success that this comic resource has enjoyed in the genre of comedy, particularly farce. Quiproquo refers to a situation in which one character mistakes another character or an object for someone or something else. ${ }^{14}$ In his book on laughter, Bergson cites the mechanism of quiproquo as an example

According to Gelzer (1960: pp. 124ff.), the bomolochos can develop into the arbiter of the agon (e.g. Demos in Knights and Dionysus in Frogs) or accompany a main character (as is the case with Blepsidemus, as well as Euelpides in Birds, Calonice in Lysistrata and Chremes in The Assemblywomen).

10 See Lanza (1989: p. 189).

11 Indeed, it can be said very little about his performance as a humorous support of Chremylus in his debate with Poverty. He comes up to the bomolochos mask: he invokes the gods out of fear; even his scatological comments before leaving reaffirm his role (613ff.). In the agon scene he intervenes twice in the dialogue and both lines are problematic $(566,580)$. Sommerstein (2001: pp. 176-177) deletes line 566, for being unmetrical - it could be an explanatory note or has suffered corruption. According to the manuscripts, line 580 was spoken by Chremylus; it was Bentley who gave it to Blepsidemus. Without these lines, Blepsidemus would not have given signs of life for more than 100 lines (see Holzinger 1940: pp. 186-188). In accordance with his minor role, the third - or fourth - actor was in charge of his performance; see Sommerstein (2001: p. 27); Thiercy (1986: p. 52); Russo (1994: p. 233).

12 This article reworks Fernández (2003): it takes into account a new hypothesis, goes more deeply into linguistics and pragmatics, and postulates new findings - some of which are even opposed to those previously listed.

13 "On trouve aussi dans cette pièce le premier - et le seul - quiproquo du théâtre d'Aristophane: quand Blepsidèmos vient voir Chrémyle pour verifier la rumeur qui dit que celui-ci et devenu riche" (Thiercy 1986: p. 179) (emphasis added).

14 A quiproquo is an example of asymmetry, or displacement, between coding and decoding. Its effectiveness as a vehicle for humour makes it a resource that has been frequently used throughout history. It is worth noting that one of the paradigmatic examples of this device can be found in a passage in Plautus's Aulularia (IV, $\mathrm{x}$ ) when Euclio and Lyconides engage in conversation: one is talking about the little pot while the other is talking about Phaedria. Neither of them realizes the error; they are each absorbed in their obsessions and therefore incapable of understanding what the other is saying. The scene is masterfully 
of what he calls "the interference of series": "Une situation est toujours comique quand elle appartient en même temps à deux séries d'événements absolument indépendantes, et qu'elle peut s'interpréter à la fois dans deux sens tout différents” (Bergson 1924: p. 45). Bergson draws attention to the double meaning of the situation: it is given one meaning by those who are taking part in it, and a second meaning by the audience. Modern discourse theories and the discipline of theatrical studies lay bare how these types of routine scenes exploit the traditional duality of theatrical dialogue: on the one hand we have the author, who is addressing the audience through the play, while on the other hand we have the situation that is being acted out (i.e. the autonomous dialogue between the characters). ${ }^{15}$ The conversation between Chremylus and Blepsidemus is based precisely on a dialogical exchange that takes place on these two levels: namely, that of the immediate interlocutor and that of the indirect recipient. In other words, it plays with this double enunciative scenario.

The dialogue has two distinct parts (332-390 and 391-415): the first is the longest and gives rise to the misunderstanding. Blepsidemus has gone to Chremylus' house because he has heard that the latter has suddenly become rich: thus, his inclusion in the scene is plausibly incorporated into the plot. The repetition of the adverb ċ $\xi \alpha \pi i v \eta \varsigma$ ("all of a sudden") in his speech - twice in just four lines $(336,339)$ - alerts us to the unusual nature of what has happened and justifies his evident disbelief: "I just don't believe it" (Ov $\pi \varepsilon$ i $\theta$ ora, 336). To add fuel to the fire, Chremylus has been acting in contravention of the customs of the period: gathering one's friends in order to share one's good fortune with

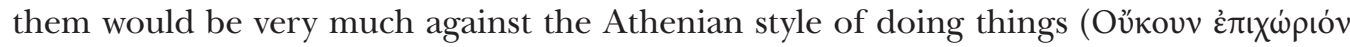
$\gamma \varepsilon \pi \rho \tilde{a} \gamma \mu$ ' $\dot{\rho} \gamma \alpha \dot{\alpha}(\varepsilon \tau \alpha u, 342)$.

As soon as he sees Blepsidemus, Chremylus promises to tell him everything, concealing nothing (343): however, he proceeds to do so in a manner that is reticent and opaque. He does not give a clear response to the questions with which Blepsidemus bombards him, or to the latter's constant interruptions; indeed, Blepsidemus is incapable of waiting for a response to his own questions: "Come on, say what you're on about" (349). However, Chremylus does not help the situation either, as he withholds information and expresses himself in a manner that is non-specific and vague, with an almost Delphic obscurity:

We're doing better than yesterday (...) (344)

There is some risk about the matter. (348)

If we succeed, it means lasting, permanent prosperity. But if we fail, we're totally ruined. (350-351)

But it's not like that; it's something quite different. (371)

recreated by Molière in L'Avare (V. iii). However, tragedies also frequently include scenes based on misunderstandings: the mistaken identity motif is present in Sophocles' Oedipus Rex and Euripides' Ion. This raises the question whether the motif originally came from tragedies before cementing itself as a staple of comedies. In this respect, it has been noticed that Ion has been a model for new comedy (Knox 1979). 
The opaqueness of Chremylus' statements opens the door to misunderstanding and

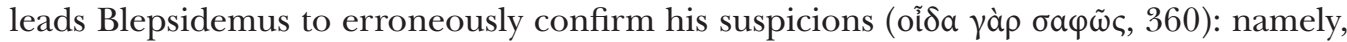
that Chremylus has gained illicit wealth (

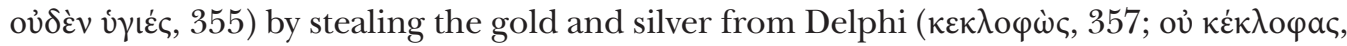

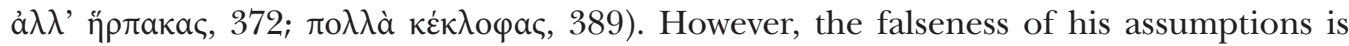
based on the opinio communis expressed in the maxim: "Ah, there's no honesty in anyone! All alike are slaves of gain!" (362-363). This idea has already been expressed in the comedy, specifically by Chremylus himself: "Everything in the world is subordinated to wealth"

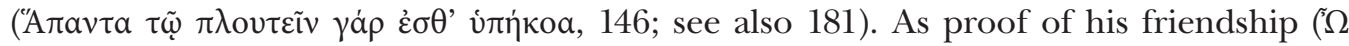
$\tau \tilde{\alpha} v, 377$; ironically $\varphi \hat{i} \lambda \omega \varsigma, 380)$ - and of the dubious morality of the time - Blepsidemus offers to bribe the rhetors in order to prevent his friend from being arrested (379). ${ }^{16}$

Chremylus appears to enjoy this off-target conjecture on the part of Blepsidemus and allows the misunderstanding to take root and grow, by delaying and rationing out the information that could clarify the matter and end the confusion. He hides the fact that he has Plutus inside his home: perhaps through fear of losing him before being able to bring about the new order of things, or perhaps through selfishness. This latter possibility should not be discounted, even after he expresses his desire to share Plutus, especially in light of the fact that the chorus leader had stated the following just a short while before: "It would be terrible (...) if I allowed someone else to take Wealth" (329-331).

A quiproquo is a failed attempt at communication. In this instance, and as we aim to demonstrate, the confusion - which is asymmetric, because it concerns just one of the speakers - is caused by a number of factors that Aristophanes develops using his habitual skill in the manipulation of language, combining them in a complex apparatus that is not always detected or appreciated, all presented in the guise of an apparently simple and humorous conversation.

From a pragmatic linguistic perspective, in principle we can observe three factors that explain the way in which the misunderstanding is developed.

\section{(i) Non-fulfilment of the premise of sincerity}

The premise of sincerity is one of the tacit - and key - rules of all discursive activity. It forms part of the contract of mutual cooperation between interlocutors, in which it is assumed that each of them will speak the truth - the so called Grice's "maxim of quality". ${ }^{17}$

16 According to Sommerstein (2001: p. 164), these rhetors are not those of the tribunal; rather, they are those of the Assembly, before whom Chremylus would have to defend himself when the authorities from Delphi presented their accusation of theft. However, Milanezi, in the latest edition for Les Belles Lettres (Coulon \& Van Daele \& Milanezi 2008: p. 39), contends that this passage contains an allusion to the actions of the sycophants, who make accusations related to the theft of public property. Additionally, this confirmation of friendship is underlined as sufficient reason for Blepsidemus to receive his share of Chremylus's newfound riches. See ll. 341 and 345: "(...) you can take a part in it, because you are one of my friends".

17 In order to achieve an effective communication, the speakers cooperate observing certain tacit rules: Grice called them 'conversational maxims' and Ducrot 'laws of discourse'. They are the maxim of quantity (in reference to the necessary and exhaustive information), the maxim of quality (about the veracity of 
Strictly speaking, in the conversation between Chremylus and Blepsidemus this premise is fulfilled, as the speakers are sincere in their assertions; they express what they are genuinely thinking or feeling. The problem resides in the fact that they both believe the other to be lying, and in consequence their mutual - and in principle unfounded - distrust undermines the possibility of believing that communication between them is possible. ${ }^{18}$

Effectively, Blepsidemus openly accuses Chremylus of talking nonsense ( $\pi$ aṽoa

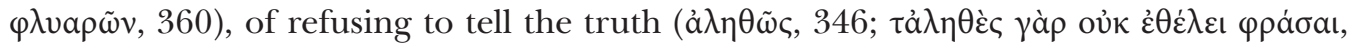
375). For his part, Chremylus goes one step further, stripping Blepsidemus' words of all of their content. He repeatedly asserts that his friend is mad, or possessed: in other words, bereft of any rational discourse that would lend any meaning to his statements

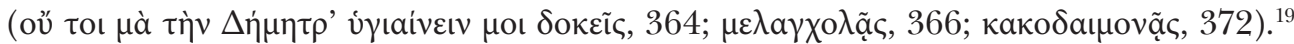

\section{(ii) Unshared 'presuppositions' ("préssuposés") ${ }^{20}$}

A 'presupposition' is an implicit assumption whose truth is taken for granted by the interlocutor; a background belief prior to the utterance. It is one of the forms of the 'implicits' of discourse; in the words of Ducrot, a speech act that forms an integral part of the meaning of what is said, regardless of the context in which it is said. ${ }^{21}$

There is no doubt that Blepsidemus assumes as a presupposition that wealth, particularly sudden wealth, can only be acquired through illicit means. It is not a thought that is exclusive to him alone; rather, it is presented as universal knowledge, shared with his community; something that everyone knows as part of the contents of an underlying encyclopedia. In fact, this 'presupposition' serves to summarize the problematic situation that provides the starting point for the comedy's intrigue: the evident inequity in the distribution of material resources, in light of the fact that prosperity is only achieved by those who are corrupt. ${ }^{22}$ This 'presupposition' governs all of Blepsidemus' discourse and also his actions: indeed, the key to the misunderstanding lies in the fact that he

assertions), the maxim of relation (about relevance) and the maxim of manner (on avoiding darkness and ambiguity); see Grice (1979).

18 At the same time as one interlocutor accuses the other of falseness in his discourse, he also believes that

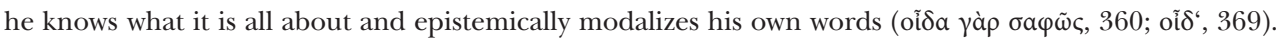

19 The association between nonsense and madness is also present in the discourse of Poverty, in reference to Chremylus and Blepsidemus (508). Likewise, the accusation of talking nonsense is related to old age (see also 517) and the cognitive decline that this entails; in that sense $\varphi \lambda v a \rho \varepsilon \dot{\omega} \omega$ could be translated as "to be senile".

20 On discoursive implicits, we follow the well-known theoretical frame called the "Théorie de l'Énonciation", developed in France for the past thirty years. We transposed the French technical terms to English but preserve them in brackets.

21 Cf. Ducrot (1984: p. 20): "Pour décrire ce statut particulier du présupposé, on pourrait dire (...) qu’il est présenté comme une évidence, comme un cadre incontestable où la conversation doit nécessairement s'inscrire, comme un élément de l'univers du discours". Regarding the implicits, see also Kerbrat-Orecchioni (1986; 2005); on speech acts see Austin (1962); Searle (1969).

22 The bond between dishonesty and wealth is a topos in the Greek imaginary. On this matter, see Dover (1974: pp. 109-112) and Fiorentini (2005), with many examples from Euripides. 
interprets his friend's statements from the perspective of this assumption. ${ }^{23}$ Blepsidemus is unaware that this frame of reference is no longer relevant, given that - through the magic of the all-powerful comedy - only honest men will become wealthy, thereby restructuring the broken relationship between merit and reward..$^{24}$

Added to the confusion that always accompanies a disparity of 'presuppositions' is the fact that, in this instance, presuppositions repel one another, cancelling each other out, to the point where it becomes impossible for both of them to coexist within the same conversation. However, it will not be easy for Blepsidemus to rid himself of his assumption, as it involves changing the way he looks at the world - it is very difficult to replace someone's belief system. Even when Chremylus finally reveals his plan to make good, just and wise men rich (386-388), ${ }^{25}$ Blepsidemus asks him in amazement: "That much have you stolen?" (389). ${ }^{26}$

\section{(iii) Manipulation of 'inferences' ("sous-entendus")}

We have already explored the mutual accusation of falseness in one's discourse. We will turn now our attention to another type of reproach: not concerning what is said, what is explicit, but concerning what is not said, what is unstated. Here, we are referring to that which is entailed, "sous-entendus". Like a presupposition, the 'inferences' (also 'implicatures') enables the speakers "de dire sans dire" (Maingueneau 2005: p. 90). However, unlike an assumption, which is dependent on the utterance, the 'inference' is dependent on the act of enunciation, and as such it cannot be understood outside of its context.

Precisely because the speakers do not trust each other, the focus of their interest is not on what is explicitly expressed; rather, it is on unravelling what is not expressed openly but can nonetheless be inferred from the information that is given. Thus, Blepsidemus understands that Chremylus is wealthy because he has committed theft $(357 ; 372 ; 389)$, while Chremylus realizes that Blepsidemus' true interest lies in receiving a share of the loot (369-370). That said, in this particular instance the two interlocutors are not on an

23 'Presuppositions' are often presented as incontestable evidences - they cannot be questioned -, so if a speaker casts doubt on them, he/she takes an aggressive position, limiting the right to speak. The 'presuppositions' must be preserved during a conversation because they define the discursive structure (Maingueneau 1976).

24 Chremylus's plan appears to oscillate between only enriching honest men, which was his first aim, and enriching all men. As demonstrated by Konstan \& Dillon (1981), these notions are a response to two different problems: the unequal distribution of wealth, and the concept of universal scarcity. Chremylus abandons his original idea when Penia forces him to defend the existence of universal plenitude. According to Dover (1972), the play does not definitively adhere to either of these two plans; Heberlein (1981), in contrast, asserts that the plan is implemented gradually. The words of Chremylus himself may provide the key here: in order to become wealthy, the hero anticipates that every man will convert to the path of decency (494-497).

25 Line 387 has been athetized by Willems; Coulon brackets it and Sommerstein preserves it.

26 Chremylus does not take advantage of Blepsidemus' ignorance, but of his illusion of knowing. For this reason, it is extremely difficult to modify his belief system - which he also shares with the rest of the fellow citizens. 
equal footing, because only Chremylus is in the right. The hero has correctly interpreted Blepsidemus' obsessive demands to know what has happened as a desire to obtain a share in the riches, in line with his role as a bomolochos concerned only with his own interests.

But why, in contrast, does Blepsidemus remain trapped in his misunderstanding? Paradoxically, it is because he correctly interprets what Chremylus' statements have led him to understand: namely, that Chremylus has become rich by committing sacrilegious and dishonest acts. Chremylus limits the information he provides to these three matters: 1. the fear he is experiencing (351); 2. the risk that the situation poses (348); and 3. his uncertainty as how everything will turn out (350-351). Although the three assertions are truthful, they restrict the content of the statements to such an extent that they manipulate the 'inferences' or 'implicatures' from his words. Chremylus says little, and what he does say is insufficient: as a result, he only half-complies with the requirement to be informative and comprehensive, which is essential to any communication. ${ }^{27}$ At the same time, the little that he does say is chosen with the aim of causing his message to be misunderstood. Let someone understand is not the same as making oneself understood, ${ }^{28}$ and Chremylus' discourse forces Blepsidemus to err, as a result of which the audience laughs with him. Therefore, it is not so much a question of incompetence on the part of Blepsidemus - although he is a bomolochos, he is no fool - as it is a question of the comic hero's ability to foster a misunderstanding.

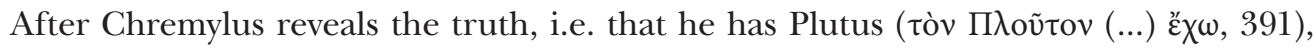
the rhythm of the dialogue speeds up and the misunderstanding is untangled. We are now in the second and final part of the dialogue. The excitement provoked by the revelation of this good news is reflected in the vertiginous succession of words that flow from both sides, to the point that the structure of the verse is broken up. Blepsidemus, still reluctant to believe what he has been told, is left speechless (a bomolochos who is lost for words, indeed!) and capable of little more than repeating the words he hears:

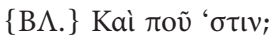

$\{\mathrm{XP}$.

$\{\mathrm{B} \Lambda$.

$\{\mathrm{XP}$.

$\{\mathrm{B} \Lambda$.

$\{\mathrm{XP}$.

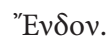

Пoṽ;

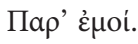

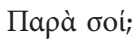

Пávv. (393)

Beyond the comedic value of this broken articulation of the dialogue, Blepsidemus' questions continue to alert us to the mistrust generated by what is being said, as evidenced by his obsessive need for Chremylus to confirm his statements. This is reinforced through

27 Chremylus breaks with the maxim of quantity (he says little, and features ellipsis) and the maxim of manner (his speech is not clear; it is ambiguous). The violation of the conversational maxims has been seen as a comic device per se (see Robson 2006: pp. 57-69).

28 See Récanati (1981) on the differentiation between "laisser entendre", "donner á entendre" and "faire entendre". 


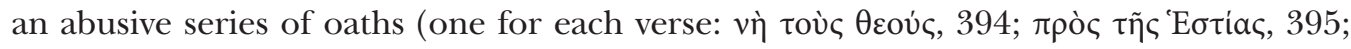

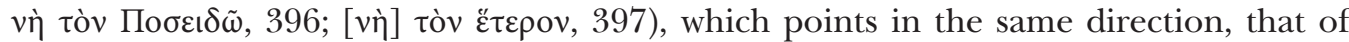
giving credibility to the discourse, and yet they seem ineffective as guarantee of truth. ${ }^{29}$ These oaths are added to the long list of such expressions that were incorporated into

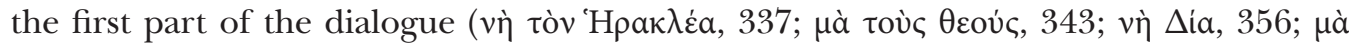

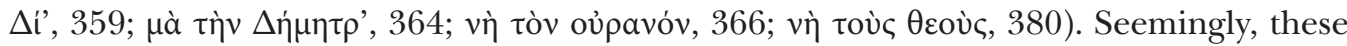
informal or conversational oaths are denuded of their religious qualities - they have lost their binding force - and are reduced to a merely expletive function, thereby articulating the emotional state of the speaker. Without a doubt, they add colour and emphasis to the colloquial discourse and are a distinctive feature of the genre, in light of the fact that oaths are not used in a similar fashion in tragedy. ${ }^{30}$ This suspicion regarding the credibility of what is being said persists to the end of the dialogue $(\lambda \dot{\varepsilon} \gamma \varepsilon \varepsilon \varsigma \grave{\alpha} \lambda \eta \theta \tilde{\eta}, 395) .{ }^{31}$ It would not be wrong to state that language is the true protagonist of this scene. This should not come as a surprise, because a quiproquo is always self-referentially discursive, and also because the scene involves a bomolochos, whose very raison d'être is language, in which the function of grotesque inversion, the very essence of the comedy genre, appears in its purest form (Carrière 1979: p. 128).

In this respect, the scene is perfectly integrated into the subjects that recur throughout the comedy. The very first verses introduce the theme of how difficult it is to interpret discourse correctly: Chremylus and his slave argue over the meaning of the words of the oracle of Apollo (45 ff.), while Plutus warns of the ability of words to state falsehoods, knowing from experience that, when asked, all men profess to be honest (107-109). Indeed, the dialogue between Blepsidemus and Chremylus is the result of the former's need to ascertain, at first hand, whether the rumours in the barber shops about his

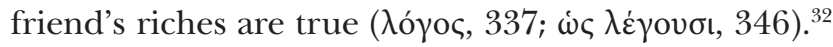

29 An oath is an invocation of superhuman powers to uphold the truth of an assertion (explicitly or implicitly). See Sommerstein (2014: p. 2): "the swearer calls down a conditional curse on him/herself to take effect if the assertion is false or if the promise is violated". According to Austin and Searle's classification of illocutionary acts, swearing is a commissive act of language, that is, it commits its addressee to a specific action. Strictly speaking, the abusive repetition of oaths in this dialogue strips them of this value to perform behabitive speech acts (an emotional reaction). Oaths persist until the end of the conversation:

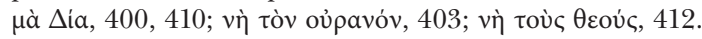

30 On oaths in comedy, see Dillon (1995), who observes that Aristophanes' characters often swear unconsciously, as a form of colloquial reflection that imitates the common usage heard in the streets; and more recently Fletcher (2012); Sommerstein (2014). Regarding oaths in general, see Sommerstein \& Fletcher (2007), Sommerstein \& Torrance (2014).

31 It is noteworthy that, when words generate mistrust, knowledge is sought via other mediums, such as body language. Indeed, Blepsidemus believes that his conjectures regarding Chremylus's criminal actions have been confirmed, and so he draws our attention to the change in the latter's manner (365) and the distracted look in his eye (367): visible signs that would give away his dishonest behaviour. In turn, Chremylus has "read" the manner and rhythm of Blepsidemus' walk, which suggest that the latter knew about the change in Chremylus's fortunes before he arrived on the scene (

32 When Blepsidemus enters the scene, he is talking to himself, immersed in his own thoughts; it is a similar entrance to that of Chremes in The Assemblywomen (746-752). 


\section{Some conclusions}

Is the encounter of Blepsidemus with Chremylus actually the only example of quiproquo in Aristophanes? Strictly speaking, there are many kinds of quiproquo. It can occur when a "character or thing is mistaken for another" (Pavis 1998: p. 216), but also when someone simply misunderstands another's words. This happens many times in Aristophanes' comedies as a consequence of double entendre jokes - particularly the ones with sexual connotations - or of other wordplays - as is the case with Lysistrata (21ff.): when the women think that the heroine is talking about a phallus, she is really telling them about her plan to end the war (due to her deliberate use of the ambiguous tò $\pi \rho \tilde{a} \gamma \mu \alpha, 22,26$ ). In fact, the scene in Plutus is the first example of quiproquo to go beyond a simple interpretive error and involve a complete reversal of meaning with significant consequences. The quiproquo that comprises this dialogue is built on an elaborate interplay between what is expressed and what remains unsaid. Unlike the more traditional forms of misunderstanding, in which each character, engrossed in their own interests, generates an entirely separate discourse - which subsequently clash at some stage during the dialogue and give rise to the misunderstanding -, in the conversation between Chremylus and Blepsidemus the two men are talking about the same thing: namely, the unexpected wealth that one of them has acquired. We see that, strictly speaking, the misunderstanding precedes the dialogue itself by virtue of having been incorporated into the implicit discursive assumptions which are not anymore shared. The change to the ideological, ethical, economic and political paradigm represented by Chremylus' programme of reforms collides with the "realist" assumption of Blepsidemus, whose frame of reference is historical and empirical in nature. The incompatibility of the two presuppositions is a source not only of humour, but also of conflict. ${ }^{33}$ A tacit disagreement is created through the collision of two different worldviews: one that follows the logic of the everyday real world, and one that responds to a comedic utopia in which everything is possible. The conversation can only take place under an unstable appearance of understanding, as there is a basic disagreement as to the meaning of what is being said. At this juncture it is worth remembering the etymology of the name Blepsidemus: according to the Didascal-

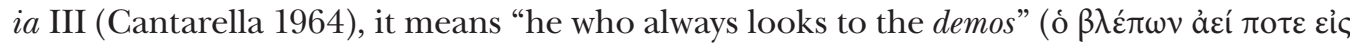

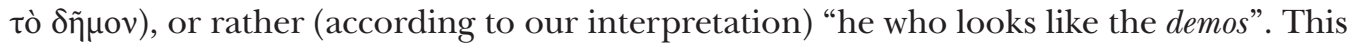
serves to assign a certain metonymic value to his discourse as an exponent of popular Athenian logic and ideology. ${ }^{34}$ As a representative of the polis of his time, the presence

33 On implicit outputs in the service of laughter, see Reichler-Beguelin (1989).

34 Effectively, another of the meanings of $\beta \lambda \varepsilon \dot{\tau} \pi \omega$ is "he who looks like" (Liddell \& Scott). Given that the name Blepsidemus brings to mind Blepyrus' name, a character in The Assemblywomen (while the name Chremylus echoes that of Chremes), Sommerstein (2001: p. 162) theorizes that it is a name typically given to old men, rather than a speaking name. However, one of the scholia, cited by Sommerstein himself, attempts to interpret its meaning etymologically: as such, it may designate a poor man, if the idea expressed is that of "he who looks to the public for assistance", or a radical democrat, in the sense of "he who looks to promote the public interest" - Kanavou (2011: p. 186), on his part, sees no support for these interpretations here. There are other names of old men that also derive from the root of $\delta$ épouaı ("peer", "see closely"), which may be associated with the problems of failing eyesight that typically occur in old age. The 
of Blepsidemus may anticipate the exemplification of the plan's consequences before it is put into practice, at the point where the action is still in limbo between the old and the new order: the encounter with Plutus makes it seem as though the crisis is resolved, while in reality everything is yet to be done. ${ }^{35}$ For his part, Chremylus is toying with this fragile stability and manipulating the inferences of his discourse, which also constitutes a transgression of the laws that make communication possible.

In general, this scene has been neglected by critics, who have considered it a simple passage of transition that delays the progress of the play's action without significant consequences (Russo 1994: p. 229). The only exception are those who defend an ironic reading of the play, for whom this dialogue provides grist for their mill. The latter group includes Flashar (1967), who casts doubt on whether a character such as Blepsidemus, who only thinks about profiting from a robbery and engaging in bribery, can be considered an honest man and thus share in the wealth, in line with Chremylus' plan to reward the just. ${ }^{36}$ We should remember that this type of reading seeks to make sense of the supposed contradictions of the play by integrating them into its meaning, which would thus remain hidden. ${ }^{37}$ Viewed from this perspective, Blepsidemus' enrichment - which we take as a given, although we do not see it - would be one of the many inconsistencies designed by the author to demonstrate how much he distances himself from the protagonist's plan.

Similarly, Maurach (1968) contends that the key role of this scene is to unmask the dishonesty of the two speakers. Like Flashar, he considers Blepsidemus to be the opposite of honest, and that Chremylus is also exposed as an avaricious man who fails to keep his promise. ${ }^{38}$ However, from the perspective of our analysis, the only one who unmasks any-

name Chremylus (336) appears immediately after that of Blepsidemus (333), in line with what appears to be a rule, according to Olson (1992: p. 308, n. 15): "When a minor free character is given a name and allowed to engage a previously anonymous hero or heroine in dialogue, this also seems to trigger naming the hero $(\ldots)$ ".

35 Gil (1996: p. 36) is of the same mind and compares the scene in question to the episodic scenes that take place during the second part of the play. Kanellakis (2020: p. 67), meanwhile, describes this scene as prothysteron, "since Wealth has not yet been cured from his blindness. This can be attributed either to the unrealism of comedy or to the very realistic fact that rumours spread fast, sometimes even before something has actually happened."

36 "Man sieht, die ganze Szene ist durchzogen von hintergründiger Ironie, die die Rechtschaffenheit des Chremylos und seiner Freunde und den darauf aufgebauten Plan als höchst fragwürdig erscheinen lässt" (Flashar 1967: p. 163).

37 They considered the irony to be the rhetorical device that underpins the text. This observation applies to both Plutus and The Assemblywomen, which are usually considered jointly in this type of interpretation. Readings of this type can be found in the work of Flashar (1967), Süss (1954), Maurach (1968), Heberlein (1981), Barkhuizen (1981), among others. Each reading has its nuances: Maurach emphasizes the procedure of unmasking; Barkhuizen argues that Aristophanes ironically reveals everything as an illusion; for Heberlein irony operates essentially on the cognitive, not on the moral, level. Recently Fiorentini (2005) explored those ironic readings in order to dismantle them; he considers inconsistencies as part of the author's dramatic system. For Ruffell (2006) both ironic and straightforward readings are unsatisfactory: "What we can say above all is that these plays are critiquing a logic of selfishness and self-interested, and exploring instead notions of trust, altruism and solidarity, not with a concrete program for revolutionary change but as progressive thought-experiments" (Ruffell 2006: p. 104).

"Die Szene sollte den scheinbaren Biedermann Chremy los entlarven, sie hat darum dieselbe Aufgabe 
thing is Chremylus, when he reveals the self-interested behaviour of his friend. In contrast, Blepsidemus - manipulated by Chremylus - engages in erroneous conjecture with regard to the latter. Readings such as these ignore the use of the misunderstanding as a comic resource, as well as the limitations imposed by the guise of buffoon. The buffoon is given a distinct style, devoid of all psychological authenticity, while his behaviour is eminently predictable; as such, he is not a sufficiently serious figure for the author to use him as a mouthpiece or to communicate a message - and one which is hidden. In our opinion, the purpose of this scene is not to cast doubt on the ethical behaviour of the interlocutors; rather, it is to demonstrate the magnitude of the challenge posed by the enormous ethical, political and social transformation that will occur imminently, when prosperity is brought within reach of everyone, or almost everyone. At the same time, it shines the spotlight onto the dialogue itself, and particularly onto that which is not said.

By pushing the boundaries of quiproquo and incorporating the misunderstanding into what is discursively implicit, rather than what is openly expressed, the dialogue is rendered more authentic and less mechanistic in its development, without losing its funny quality. Because the misunderstanding is induced 'consciously' by the hero, the audience's laughter reflects their enjoyment at sharing this knowledge with him. This complicity probably reinforces the audience's identification with the protagonist's ideals, interests and plans. ${ }^{39}$ Hero and audience are united in the same feeling of superiority that characterizes those who share a joke at the expense of the same specific target. ${ }^{40}$ However, the situation is resolved without any animosity, as Blepsidemus is not a suitable candidate for the violent treatment reserved for an antagonist. On the contrary, as bomolochos he is the most genuine expression of humour, so comedy accommodates him as Chremylus' closest ally thereafter.

wie die Penia-Szene, die H. Flashar so treffend interpretiert hat (163 ff.): sie sollte dem Zuschauer zeigen, daß hier Figuren auftreten mit Ansprüchen, denen sie nicht genügen” (Maurach 1968: p. 9). We do not deny that Blepsidemus' offer to collaborate is dishonest (370, 380-381); however, we do not believe that this is the focal point of the scene. Rather, it can be seen as an example of typically Athenian thought and behaviour.

39 Likewise, Heberlein contends that a key function of this scene is to make the audience identify more strongly with the hero, by making them share the same feeling of superiority: "im Grunde sind es also Held und Zuschauer zusammen, die sich da über 60 Verse ein Spielchen auf Kosten des B. machen. Neben der Charakterisierung des Blepsidemos hat dies noch den anderen Effekt, daß der Zuschauer im Gefühl gemeinsamer Überlegenheit stärker an den Helden gebunden wird” Heberlein (1981: p. 36). This author considers Blepsidemus as a double of the informer; both suspect the interlocutor of theft and lies, and adjudge justice to themselves ( he postulates the same mask for both of them, performed also by the same actor.

40 See Purdie (1993: p. 69): "Paradigmatically, to the extent that a text is joking, the author position and the Audience share and affirm their own propriety across characters who have enough discursive ability to make it worthwhile to construct them as objects of laughter whose ineptness distinguishes 'them' from 'us'." Humour theories point at a scenario shared by three characters: the one who laughs, the victim and the accomplice witness. The latter is required to face an interpretive effort; in this case, to perceive the intentions of the speaker and at the same time to recognize the misunderstanding: laughter is a reward for his/her efforts. Comic heroes are usually associated with manipulating discursive conventions to their advantage. On humour in Aristophanes, see Robson (2006). 


\section{Bibliography}

Austin, J. (1962). How to Do Things with Words. Cambridge (MA): Harvard University Press.

Barkhuizen, J. (1981). The Plutus of Aristophanes. Acta Classica, 24, 17-22.

Bergson, H. (1924). Le rire. Essai sur la signification du comique. Paris: Éditions Alcan.

Beta, S. (2004). Il linguaggio nelle commedie di Aristofane. Parola positiva e parola negativa nella commedia antica. Roma: Accademia Nazionale dei Lincei.

Caciagli, S., Corradi, M., \& Regali, M. (2016). Buffoni e 'bomolochoi'. Lessico del comico, 1, 135-154.

Cantarella, R. (Ed.). (1964). Aristofane, Le Commedie. Milano: Istituto Editoriale Italiano.

Carrière, J. C. (1979). Le carnaval et la politique. Une introduction à la comédie grecque, suivre d'un choix de fragments. Paris: Les Belles Lettres.

Chantraine, P. (1999). Dictionnaire étymologique de la langue grecque. Historie des mots (Avec un supplément sous la direction de A. Blanc, Ch. de Lamberterie, J-P. Perpillon). Paris: Klincksieck.

Cornford, F. (1914). The Origin of Attic Comedy. London: Edward Arnold.

Coulon, V., Van Daele, H., \& Milanezi, S. (Eds.). (2008). Aristophane: Ploutos. Paris: Les Belles Lettres.

David, E. (1984). Aristophanes and Athenian Society of the Early Fourth Century B.C. Leiden: Brill.

Dearden, C. (1976). The Stage of Aristophanes. London: Athlone Press.

Dillon, M. (1987). Topicality in Aristophanes' Ploutos. Classical Antiquity, 6, 155-183.

Dillon, M. (1995). By Gods, Tongues, and Dogs: The Use of Oaths in Aristophanic Comedy. Greece and Rome, 42(2), 135-151.

Dover, K. (1972). Aristophanic Comedy. Berkeley - Los Angeles: University of California Press.

Dover, K. (1974). Greek Popular Morality in the Time of Plato and Aristotle. Berkeley: University of California Press.

Ducrot, O. (1984). Le dire et le dit. Paris: Minuit.

Elam, K. (1980). The Semiotics of Theatre and Drama. New York: Methuen.

Fernández, C. N. (2003). Pretensión de un malentendido: Crémilo y Blepsidemo en Plutos de Aristófanes (vv. 335-414). In P. Cavallero, R. Buzón, D. Frenkel, \& A. Nocito (Eds.), Koronís. Homenaje a Carlos Ronchi March (pp. 180-189). Buenos Aires: Universidad de Buenos Aires.

Fiorentini, L. (2005). A proposito dell'esegesi 'ironica' per l'ultimo Aristofane. Eikasmos, 16, 111-123. Flashar, H. (1967). Zur Eigenart des aristophanischen Spätwerks. Poetica, 1, 154-175.

Fletcher, J. (2012). Performing Oaths in Classical Greek Drama. Cambridge: University Press.

Frontisi-Ducroux, F. (1984). La Bomolochia: autour de l'embuscade ä l'autel. Cahiers du Centre Jean Bérard, 9, 29-50.

Gelzer, T. (1960). Der epirrhematische Agon bei Aristophanes. Untersuchungen zur Struktur der attischen alten Komödie. München: Beck.

Gil, L. (1996). Aristófanes. Madrid: Gredos.

Grice, P. (1979). Logique et conversation. Communications, 30, 57-72.

Heberlein, F. (1981). Zur Ironie im 'Plutos' des Aristophanes. Würzburger Jahrbücher für die Altertumswissenschaft, 7, 27-49.

Holzinger, K. (1940). Kritisch-exegetischer Kommentar zu Aristophanes’ Plutos. Wien - Leipzig: Kommissions-Verleger der Akademie der Wissenschaften in Wien. 
Issacharoff, M. (1985). Le spectacle du discours. Paris: Corti.

Janko, R. (1984). Aristotle on Comedy. Towards a Reconstruction of Poetics II. Berkeley: University of California Press.

Kanavou, N. (2011). Aristophanes' Comedy of Names. A Study of Speaking Names in Aristophanes. Berlin: De Gruyter.

Kanellakis, D. (2020). Aristophanes and the Poetics of Surprise. Berlin: De Gruyter.

Kerbrat-Orecchioni, C. (1986). L'implicite. Paris: A. Colin.

Kerbrat-Orecchioni, C. (2005). Le discours en interaction. Paris: A. Colin.

Kidd, S. (2012). The Meaning of bōmolokhos in Classical Attic. Transactions of the American Philological Association, 142(2), 239-255.

Knox, B. M. W. (1979). Euripidean Comedy. In Word and Action: Essays on the Ancient Theater (pp. 250-274). Baltimore: Johns Hopkins University Press.

Komornicka, A. (1964). Métaphores, personnification et comparaisons dans l'oeuvre d'Aristophane. Warszawa: Archivum Filologiczne.

Konstan, D., \& Dillon, M. (1981). The ideology of Aristophanes' Wealth. American Journal of Philology, 102, 371-394.

Lanza, D. (1989). Lo spazio scenico dell'attore comico. In L. De Finis (Ed.), Scena e spettacolo nell'antichità (pp. 179-191). Firenze: Olschki.

MacDowell, D. (1995). Aristophanes and Athens. An Introduction to the Plays. Oxford: University Press.

MacDowell, D. (2002). Review of Aristophanes, Wealth, by A. H. Sommerstein. The Classical Review, 52, 245-246.

Maingueneau, D. (1976). Initiation aux méthodes de l'analyse du discours: Problèmes et perspectives. Paris: Hachette.

Maingueneau, D. (2005). Pragmatique pour le discours littéraire. Paris: Armand Colin.

Maurach, G. (1968). Interpretationen zur attischen Komödie. Acta Classica, 11, 1-24.

McGlew, J. (1997). After Irony: Aristophanes' Wealth and Its Modern Interpreters. American Journal of Philology, 118, 35-53.

McLeish, K. (1980). The Theatre of Aristophanes. Bath: Thames and Hudson.

Newiger, H-J. (1957). Metapher und Allegorie. Studien zu Aristophanes. München: Beck.

Olson, S. (1990). Economics and Ideology in Aristophanes' Wealth. Harvard Studies in Classical Philology, 93, 223-242.

Olson, S. (1992). Names and Naming in Aristophanic Comedy. Classical Quarterly, 42, 304-319.

Orfanos, C. (2000). Autour de l'autel comique. Pallas, 54, 41-59.

Pavis, P. (1998). Dictionary of the Theatre. Terms, Concepts and Analysis. Toronto: University of Toronto Press.

Purdie, S. (1993). Comedy. The Mastery of Discourse. Toronto: University of Toronto Press.

Récanati, F. (1981). Les Énoncés performatifs. Contribution à la pragmatique. Paris: Minuit.

Reichler-Beguelin, M-J. (1989). Pour une rhétorique des contenus implicites: l'exemple des mots d'esprit. Études de Lettres, 1, 7-23.

Revermann, M. (2006). Comic Business. Theatricality, Dramatic Technique, and Performance Contexts of Aristophanic Comedy. Oxford: University Press.

Robson, J. (2006). Humour, Obscenity and Aristophanes. Tübingen: Gunter Narr. 
Ruffell, I. (2006). A Little Ironic, Don't You Think? Utopian Criticism and the Problem of Aristophanes' Late Plays. In L. Kozak, \& J. Rich (Eds.), Playing around Aristophanes (pp. 65-104). Oxford: University Press.

Ruffell, I. (2014). Character Types. In M. Revermann (Ed.), The Cambridge Companion to Greek Comedy (pp. 147-167). Cambridge: University Press.

Russo, C. (1994). Aristophanes. An Author for the Stage. London - New York: Routledge.

Searle, J. (1969). Speech Acts. Cambridge: University Press.

Sfyroeras, P. (1996). What Wealth Has to Do with Dionysos: From Economy to Poetics in Aristophanes' Plutus. Greek Roman and Byzantine Studies, 36, 231-261.

Sommerstein, A. (Ed.). (2001). Aristophanes: Wealth. Warminster: Aris and Phillips.

Sommerstein, A. (2014). The Informal Oaths. In A. Sommerstein, \& I. Torrance (Eds.), Oaths and Swearing in Ancient Greece (pp. 315-347). Berlin: De Gruyter.

Sommerstein, A., \& Fletcher, J. (Eds.). (2007). Horkos: The Oath in Greek Society. Exeter: Bristol Phoenix Press.

Sommerstein, A., \& Torrance, I. (Eds.). (2014). Oaths and Swearing in Ancient Greece. Berlin: De Gruyter.

Strauss, B. (1986). Athens after the Peloponnesian War. Class, Faction and Policy 403-386 BC. London: Croom Helm.

Süss, W. (1908). Zur Komposition der altattischen Komödie. Rheinisches Museum, 63, 12-38.

Süss, W. (1954). Scheinbare und wirkliche Inkongruenzen in den Dramen des Aristophanes. Rheinisches Museum, 97, 115-159; 229-254; 289-316.

Thiercy, P. (1986). Aristophane: fiction et dramaturgie. Paris: Les Belles Lettres.

Tottaro, P. (2016). La Ricchezza in persona nel Pluto di Aristofane. Lexis, 34, 144-158.

Ubersfeld, A. (1977). Lire le théâtre. Paris: Éditions sociales.

Ubersfeld, A. (1981). L'école du spectateur. Paris: Éditions sociales.

Wilkins, J. (2000). The Boastful Chef: The Discourse of Food in Ancient Greek Comedy. Oxford: University Press.

Prof. Claudia N. Fernández / claudia.fernandez@conicet.gov.ar

Center for Hellenic Studies

National University of La Plata, Faculty of Humanities and Education Sciences

CONICET

Calle 51 e/ 124 y 125, (1925) Ensenada, Argentina 